\title{
ANALISIS FAKTOR-FAKTOR YANG MEMPENGARUHI PRODUKSI USAHA IKAN PATIN (Pangasius Sp) DALAM KERAMBA DI KELURAHAN PAHANDUT SEBERANG KOTA PALANGKA RAYA
}

\author{
${ }^{1}$ Tia Arista Fitri, ${ }^{2}$ Maleha \\ ${ }^{1}$ Alumnus Program Studi Agribisnis Fakultas Pertanian Universitas Palangka Raya \\ ${ }^{2}$ Staf Pengajar Program Studi Agribisnis Fakultas Pertanian Universitas Palangka Raya \\ Email: malehaplk@gmail.com
}

\begin{abstract}
ABSTRAK
Penelitian ini bertujuan untuk menganalisis faktor-faktor yang mempengaruhi produksi ikan patin dalam keramba, Kelurahan Pahandut Seberang Kota Palangka Raya. Penelitian ini dilaksanankan dari bulan April-Juni 2019. Metode yang digunakan dalam penelitian ini adalah metode survei. Metode yang digunakan dalam penentuan lokasi penelitian adalah purposive dan metode pengambilan sampel menggunakan metode simpel random sampling dengan jumlah responden 30 pembudidaya ikan. Analisis yang digunakan adalah regresi linier berganda. Data-data penelitian berdistribusi dengan normal, nilai koefisien determinasi 0,872 atau $87,2 \%$. Berdasarkan hasil penelitian bahwa faktor produksi yang berpengaruh secara signifikan adalah modal, pakan dan frekuensi pemeliharaan, sementara pendidikan, usia, pengalaman, berpengaruh tidak signifikan terhadap produksi ikan patin dalam keramba.
\end{abstract}

Kata Kunci : keramba, ikan patin, faktor produksi.

\section{ABSTRACT}

This study aims to analyze the factors that influence the production of catfish in cages, Pahandut Seberang Village, Palangka Raya City. This research was conducted from April to June 2019. The method used in this study was the survey method. The method used in determining the location of the study is Purposive and the sampling method using a simple random sampling method with the number of respondents 30 fish farmers. The research data are normally distributed, the coefficient of determination is 0.872 or $87,2 \%$. Based on the results of the study that the factors of production that have a significant effect are capital, feed, the maintenance intensity, education, age, experience, is not significant for the production of catfish in cages.

Keywords: cages, catfish, production factors. 


\section{PENDAHULUAN}

\section{Latar Belakang}

Subsektor perikanan mempunyai peran dalam menunjang perkembangan perekonomian nasional. Keuntungan nyata yang dapat dirasakan masyarakat yaitu sebagai sumber lapangan pekerjaan, meningkatkan pendapatan produsen dan sebagai sumber pangan hewani yang bernilai gizi yang tinggi. Pembangunan perikanan pada saat ini diarahkan untuk peningkatan konstribusi subsektor perikanan dalam menunjang terciptanya pertanian yang maju, efisien dan tangguh. Selanjutnya, pembangunan perikanan bertujuan untuk mewujudkan stabilitas ekonomi yang seimbang antara industri dan pertanian yang mendukung, sekaligus pengembangan desa dan meningkatkan taraf hidup pengusaha ikan. Salah satu upaya untuk meningkatkan produksi perikanan adalah melalui teknik budidaya dan pola pengembangan dengan cara ekstensifikasi dan intensifikasi terutama di daerah-daerah yang memiliki potensi dan prospek yang cukup tinggi, baik budidaya laut, pantai, danau dan air tawar (Kurnianti, 2017).

Budidaya perikanan merupakan salah satu komponen yang penting di sektor perikanan. Usaha ini juga mampu berperan dalam menunjang persediaan pangan nasional, penciptaan lapangan kerja dan sebagai sumber pendapatan. Pada waktu yang akan datang konsumsi ikan akan selalu meningkat, hal ini dikarenakan bertambahnya jumlah penduduk serta kesadaran masyarakat akan kecukupan gizi (Rukmana, 2015).
Pembangunan kelautan dan perikanan di Provinsi Kalimantan Tengah masih memerlukan perhatian terutama dalam peningkatan kesejahteraan masyarakat dan pertumbuhan ekonomi dengan tetap memperhatikan pengelolaan sumberdaya alam yang berkelanjutan dan sekaligus memelihara daya dukungnya. Apabila potensi ini dapat dimanfaatkan dengan maksimal serta manajemen yang baik dan sesuai dengan kriteria teknis budidaya maka tentunya akan memberikan kesejahteraan bagi masyarakat pembudidaya ikan di Provinsi Kalimantan Tengah (Dinas Kelautan dan Perikanan Provinsi Kalimantan Tengah, 2015).

Berdasarkan data Badan Pusat Statistik tahun 2013 tentang penyebaran rumah tangga usaha pertanian di Kalimantan Tengah, yang menarik terjadi pada subsektor perikanan. Rumah tangga usaha perikanan yang semula banyak mengandalkan perikanan tangkap dimana dari sisi produktivitasnya masih tergantung dengan kondisi alam dan musim, beralih ke usaha budidaya perikanan, baik budidaya terhadap ikan laut maupun di perairan umum. Pada tahun 2013 telah terjadi penurunan jumlah rumah tangga pada subsektor perikanan, yang diakibatkan penurunan besar-besaran pada perikanan tangkap. Meskipun demikian, jumlah rumah tangga perikanan budidaya justru meningkat lebih pesat (Badan Pusat Statistik Sensus Pertanian Kalimantan Tengah, 2013).

Keberhasilan produksi dalam budidaya perikanan ditentukan oleh banyak faktor yang terdiri dari faktor internal 
(faktor yang dapat dikendalikan) dan faktor eksternal (faktor yang tidak dapat dikendalikan). Faktor internal dalam kegiatan usaha pembesaran ikan dalam keramba terdiri dari faktor modal, faktor kultur teknis yaitu frekuensi pemeliharaan, jumlah bibit dan tenaga kerja dan faktor nelayan yaitu pendidikan, pengalaman berusaha, dan usia pembudidaya. Faktor eksternal dalam usaha pembesaran ikan dalam keramba diantaranya adalah suhu, cuaca, musim, dan kualitas air (Hidayatullah, 2016).

Tabel 1. Jumlah Rumah Tangga Petani Ikan Dalam Keramba di Kecamatan Pahandut, 2016

\begin{tabular}{clcc}
\hline No & Kelurahan & $\begin{array}{c}\text { Jumlah Petani Ikan } \\
\text { (Orang) }\end{array}$ & $\begin{array}{c}\text { Jumlah Keramba } \\
\text { (unit) }\end{array}$ \\
\hline 1 & Pahandut & 28 & 39 \\
2 & Panarung & - & - \\
3 & Langkai & 20 & 30 \\
4 & Tumbang Rungan & 30 & 45 \\
5 & Pahandut Seberang & 620 & 998 \\
6 & Tanjung Pinang & 24 & 34 \\
\hline & Kecamatan Pahandut & 722 & 1146 \\
\hline
\end{tabular}

Sumber : Laporan Tahunan Kecamatan Pahandut Tahun 2017

Tabel 1 menunjukan jumlah rumah tangga petani ikan dalam keramba di Kecamatan Pahandut yang paling banyak terdapat di kelurahan Pahandut Seberang jumlah pembudidaya pada tahun 2016 sebanyak 620 orang petani ikan dengan unit keramba sebanyak 998 unit. Sementara berdasarkan hasil survei yang dilakukan oleh peneliti di Kelurahan Pahandut Seberang pada tahun 2018 jumlah pemudidaya ikan patin dalam keramba yang masih aktif dalam kegiatan budidaya sebanyak 112 pembudidaya.

Tujuan Penelitian ini untuk menganalisis faktor-faktor yang mempengaruhi produksi ikan patin dalam keramba di Kelurahan Pahandut Seberang.

\section{METODE PENELITIAN}

Penelitian ini dilaksanakan di Kelurahan Pahandut Seberang, Kecamatan Pahandut, Kota Palangka Raya. Pemilihan lokasi ini dilakukan secara sengaja (purposive) dengan pertimbangan bahwa Kelurahan Pahandut Seberang merupakan daerah sentral produksi ikan sistem keramba di Kota Palangka Raya. Dilaksanakan selama tiga bulan yaitu pada bulan April Juni tahun 2019.

Sampel petani ikan patin yang dimaksud dalam penelitian ini adalah petani yang mempunyai mata pencaharian sebagai petani ikan patin dalam keramba yang ada di Kelurahan Pahandut Seberang 
Kecamatan Pahandut, Kota Palangka Raya. Metode penarikan sampel dalam penelitian ini menggunakan metode (Simple Random Sampling) yang artinya semua populasi memiliki kesempatan yang sama untuk dipilih sebagai sampel, berdasarkan teori Arikunto (2010), serta karena sifat sampel yang homogen maka jumlah sampel dalam penelitian ini diambil sebanyak $25 \%$ yaitu 22 orang yang kemudian dibulatkan menjadi 30 petani ikan patin dalam keramba yang akan diambil secara acak dan diharapkan dapat mewakili seluruh petani secara keseluruhan.

Jenis data yang dipergunakan dalam penelitian ini adalah data primer dan data sekunder. Data primer dalam penelitian ini berupa : usia petani, jumlah keramba, banyaknya produksi, pendidikan petani, lamanya berusahatani ikan, modal usaha yang digunakan, jumlah keramba yang dimiliki petani, banyaknya pakan yang digunakan dan intensitas pemeliharaan. Dalam penelitain ini data diperoleh dari Badan Pusat Statistik Kalimantan Tengah dan Dinas Perikanan kota Palangka Raya Kalimantan Tengah.

Pengolahan data yang bersifat kuantitatif yang telah dikumpulkan dari lapangan diolah dengan bantuan alat hitung (kalkulator), aplikasi Ecxel 2013 dan SPSS. Data yang bersifat kualitatif diuraikan secara deskriftif.

Analisis data pada penelitian ini menggunakan analisis faktor-faktor yang mempengaruhi produksi ikan patin dalam keramba di Kelurahan Pahandut Seberang dengan menggunakan metode analisis regresi linear berganda. Analisis yang digunakan dilakukan untuk menguji pengaruh variabel modal $\left(\mathrm{X}_{1}\right)$, pakan $\left(\mathrm{X}_{2}\right)$, pendidikan $\left(\mathrm{X}_{3}\right)$, usia petani $\left(\mathrm{X}_{4}\right)$, pengalaman $\left(\mathrm{X}_{5}\right)$ dan frekuensi pemeliharaan $\left(\mathrm{X}_{6}\right)$ terhadap produksi ikan patin dalam keramba. Maka persamaan yang digunakan dalam penelitian ini adalah:

$$
\begin{aligned}
& Y=a+b_{1} X_{1}+b_{2} X_{2}+b_{3} X_{3}+b_{4} X_{4}+ \\
& b_{5} X_{5}+b_{6} X_{6}+e i
\end{aligned}
$$

Dimana :

$\mathrm{Y}=$ Produksi ikan patin sistem keramba $(\mathrm{Kg})$

$\mathrm{X}_{1}=\operatorname{Modal}(\mathrm{Rp})$

$\mathrm{X}_{2}=$ Jumlah Pakan $(\mathrm{Kg})$

$\mathrm{X}_{3}=$ Pendidikan (Tahun)

$\mathrm{X}_{4}=$ Usia petani (Tahun)

$\mathrm{X}_{5}=$ Pengalaman berusahatani ikan (Tahun)

$\mathrm{X}_{6}=$ Frekuensi Pemberian Pakan (kali/hari)

$\mathrm{a}=$ Nilai konstanta

$b_{1}, b_{2}, b_{3}, b_{4}, b_{5}$ dan $b_{6}=$ Koefisien regresi

ei $=$ Faktor pengganggu (error)

Uji Statistik

a. Pengujian Koefisien Determinasi $\left(\mathrm{R}^{2}\right)$

Analisis ini untuk melihat seberapa besar pengaruh variabel independen atau bebas dalam menerangkan secara keseluruhan terhadap variabel dependen atau terikat serta pengaruhnya. Secara potensial dapat diketahui dari besarnya nilai koefisien determinasi $\left(\mathrm{R}^{2}\right)$. Nilai $\mathrm{R}^{\mathbf{2}}$ digunakan untuk menguji besarnya sumbangan variabel bebas yang diteliti terhadap variabel terikat. Jika $\mathrm{R}^{\mathbf{2}}$ semakin besar (mendekati satu), maka sumbangan variabel bebas terhadap variabel terikat semakin besar. Sebaliknya apabila $\mathrm{R}^{2}$ semakin kecil (mendekati nol), maka besarnya sumbangan variabel bebas terhadap variabel terikat semakin kecil. Jadi besarnya $\mathrm{R}^{2}$ berada diantara $0-1$ atau $0<$ 
$\mathrm{R}^{2}<1$, apabila $\mathrm{R}^{2}$ sama dengan 0 maka garis regresi tidak dapat digunakan untuk membuat ramalan variabel dependen, sebab variabel-variabel yang dimasukkan ke dalam persamaan regresi tidak mempunyai pengaruh varian variabel dependen adalah 0 . Tidak ada ukuran yang pasti berapa besarnya $\mathrm{R}^{2}$ untuk mengatakan bahwa suatu pilihan variabel sudah tepat. Jika $\mathrm{R}^{2}$ semakin besar atau mendekati 1, maka model makin tepat.

\section{b. Uji F Statistik}

Uji ini digunakan untuk mengetahui pengaruh variabel independen secara signifikan terhadap variabel dependen. Dimana jika $\mathrm{F}$ hitung $\leq \mathrm{F}$ tabel, maka $\mathrm{H}_{0}$ diterima atau variabel independen secara bersama-sama tidak memiliki pengaruh terhadap variabel dependen (tidak signifikan) dengan kata lain perubahan yang terjadi pada variabel terikat tidak dapat dijelaskan oleh perubahan variabel independen, dimana tingkat signifikansi yang digunakan yaitu 5\%. Analisis ini digunakan untuk mengukur seberapa besar pengaruh variabel independen (modal, pakan, pendidikan, usia, pengalaman dan frekuensi pemeliharaan) terhadap variabel dependen (produksi ikan patin (Pangasius sp) dalam keramba). Langkah-langkah pengujian sebagai berikut:

1. Menentukan hipotesis

$\mathrm{H}_{0}$ : Variabel modal $\left(\mathrm{X}_{1}\right)$, pakan $\left(\mathrm{X}_{2}\right)$, pendidikan $\left(\mathrm{X}_{3}\right)$, usia petani $\left(\mathrm{X}_{4}\right)$, pengalaman $\left(\mathrm{X}_{5}\right)$ dan Jumlah frekuensi pemeliharaan $\left(\mathrm{X}_{6}\right)$ secara simultan tidak berpengaruh nyata terhadap produksi ikan patindalam keramba (Y).
$\mathrm{H}_{\mathrm{a}}$ : Variabel (modal $\left(\mathrm{X}_{1}\right)$, pakan $\left(\mathrm{X}_{2}\right)$, pendidikan $\left(\mathrm{X}_{3}\right)$, usia petani $\left(\mathrm{X}_{4}\right)$, pengalaman $\left(\mathrm{X}_{5}\right)$ dan Jumlah frekuensi pemeliharaan $\left(\mathrm{X}_{6}\right)$ secara simultan berpengaruh nyata terhadap produksi ikan patin dalam keramba (Y).

2. Probabilitas tingkat kesalahan yang digunakan sebesar 5\% $(0,05)$.

3. Kriteria pengujian

- Jika probabilitas tingkat kesalahan $\leq$ $5 \%$, maka signifikan, artinya $\mathrm{H}_{0}$ ditolak dan $\mathrm{H}_{\mathrm{a}}$ diterima.

- Jika probabilitas tingkat kesalahan > $5 \%$, maka tidak signifikan, artinya $\mathrm{H}_{0}$ diterima dan $\mathrm{H}_{\mathrm{a}}$ ditolak.

4. Pengambilan kesimpulan berdasarkan keputusan mengenai penerimaan atau penolakan suatu hipotesis.

\section{c. Uji Parsial (Uji t Statistik)}

Uji ini digunakan untuk mengetahui apakah masing-masing variabel independen secara sendiri-sendiri mempunyai pengaruh secara signifikan terhadap variabel dependen. Dengan kata lain, untuk mengetahui apakah masing-masing variabel independen dapat menjelaskan perubahan yang terjadi pada variabel dependen secara nyata.

Analisis ini digunakan untuk menguji pengaruh secara prsial antara modal $\left(\mathrm{X}_{1}\right)$, pakan $\left(\mathrm{X}_{2}\right)$, pendidikan $\left(\mathrm{X}_{3}\right)$, usia petani $\left(\mathrm{X}_{4}\right)$, pengalaman $\left(\mathrm{X}_{5}\right)$ dan frekuensi pemeliharaan $\left(\mathrm{X}_{6}\right)$ terhadap produksi ikan patin (Pangasius sp) dalam keramba. Langkah-langkah pengujian sebagai berikut:

1. Menentukan hipotesis 
$\mathrm{H}_{0}$ : Variabel modal $\left(\mathrm{X}_{1}\right)$, pakan $\left(\mathrm{X}_{2}\right)$, pendidikan $\left(\mathrm{X}_{3}\right)$, usia petani $\left(\mathrm{X}_{4}\right)$, pengalaman $\left(\mathrm{X}_{5}\right)$ dan Jumlah frekuensi pemeliharaan $\left(\mathrm{X}_{6}\right)$ secara persial tidak berpengaruh nyata terhadap produksi ikan patin dalam keramba (Y).

$\mathrm{H}_{\mathrm{a}}$ : Variabel modal $\left(\mathrm{X}_{1}\right)$, pakan $\left(\mathrm{X}_{2}\right)$, pendidikan $\left(\mathrm{X}_{3}\right)$, usia petani $\left(\mathrm{X}_{4}\right)$, pengalaman $\left(\mathrm{X}_{5}\right)$ dan frekuensi pemeliharaan $\left(\mathrm{X}_{6}\right)$ secara persial berpengaruh nyata terhadap produksi ikan patin (Pangasius $s p$ ) dalam keramba $(\mathrm{Y})$.

2. Probabilitas tingkat kesalahan yang digunakan sebesar 5\% $(0,05)$.

3. Kriteria Pengujian
- Jika probabilitas tingkat kesalahan $\leq$ $5 \%$, maka signifikan, artinya $\mathrm{H}_{0}$ ditolak dan $\mathrm{H}_{\mathrm{a}}$ diterima.

- Jika probabilitas tingkat kesalahan > $5 \%$, maka tidak signifikan, artinya $\mathrm{H}_{0}$ diterima dan $\mathrm{H}_{\mathrm{a}}$ ditolak.

4. Pengambilan kesimpulan berdasarkan keputusan mengenai penerimaan atau penolakan suatu hipotesis.

\section{HASIL DAN PEMBAHASAN}

\section{Pengujian Regresi Linier Berganda}

Hasil analisis faktor-faktor yang mempengaruhi produksi usaha ikan patin dalam keramba di Kelurahan Pahandut Seberang menggunakan aplikasi SPSS dapat dilihat pada Tabel 2.

Tabel 2. Hasil Uji Analisis Regresi Linier Berganda Pada Faktor-Faktor yang Mempengaruhi Produksi Usaha Ikan Patin Dalam Keramba di Kelurahan Pahandut Seberang Kota Palangka Raya.

\begin{tabular}{|c|c|c|c|c|c|}
\hline \multicolumn{3}{|c|}{ Variabel } & $\begin{array}{c}\text { Koefisien } \\
\text { Regresi }\end{array}$ & Standar Eror & Signifikan \\
\hline \multicolumn{3}{|c|}{ Konstanta } & $-0,267$ & 1,272 & 0,836 \\
\hline $\mathrm{X} 1$ & \multicolumn{2}{|c|}{ (Modal) } & $0,023^{* * *}$ & 0,007 & 0,002 \\
\hline $\mathrm{X} 2$ & \multicolumn{2}{|c|}{ (Pakan) } & $0,237^{* *}$ & 0,106 & 0,036 \\
\hline $\mathrm{X} 3$ & \multicolumn{2}{|c|}{ (Pendidikan) } & 0,049 & 0,066 & 0,469 \\
\hline $\mathrm{X} 4$ & \multicolumn{2}{|c|}{ (Usia) } & $-0,042$ & 0,035 & 0,237 \\
\hline $\mathrm{X} 5$ & \multicolumn{2}{|c|}{ (Pengalaman) } & 0,058 & 0,056 & 0,313 \\
\hline X6 & \multicolumn{2}{|c|}{ (Frekuensi Pemeliharaan) } & $0,226^{* * *}$ & 0,088 & 0,017 \\
\hline$\overline{\mathrm{R}}$ & & $=0,934^{\mathrm{a}}$ & \multicolumn{3}{|c|}{ Sig $=0,002$ Taraf Kepercayaan $=99,8 \%$} \\
\hline $\mathrm{R}-S$ & uare & $=0,872$ & \multicolumn{3}{|c|}{ Sig $=0,036$ Taraf Kepercayaan $=96,4 \%$} \\
\hline F-hi & Ing & $=26,089$ & \multicolumn{3}{|c|}{ Sig $=0,017$ Taraf Kepercayaan $=98,3 \%$} \\
\hline $\mathrm{F}$ ta & & $=2,51$ & & & \\
\hline \multicolumn{3}{|c|}{ Darbin Watson $=2,019$} & & & \\
\hline
\end{tabular}


Berdasarkan hasil analisis uji regresi dapat dibuat persamaan fungsi produksi sebagai berikut :

$$
\begin{gathered}
Y=-0,267+0,023 X_{1}+0,237 X_{2}+0,049 X_{3}- \\
0,042 X_{4}+0,058 X_{5}+0,226 X_{6}
\end{gathered}
$$

Terdapat tiga variabel yang berpengaruh signifikan yaitu variabel modal, pakan dan frekuensi pemeliharaan. Dari persamaan di atas dapat diartikan bahwa setiap penambahan variabel modal sebanyak Rp.1 maka produksi akan bertambah sebesar 0,023 kg. Apabila pakan ditambah sebesar $1 \mathrm{~kg}$ maka produksi ikan patin akan bertambah sebesar 0,237 kg. Apabila variabel frekunsi pemeliharaan meningkat sebanyak 1 kali dalam sehari maka produksi ikan patin akan meningkat sebesar $0,226 \mathrm{~kg}$.

\section{Uji Statistik}

\section{a. Pengujian Koefisien Determinasi $\left(\mathrm{R}^{\mathbf{2}}\right)$}

Berdasarkan Tabel 3, hasil analisis nilai koefisien determinasi $\left(\mathrm{R}^{2}\right)$ sebesar 0,872 atau $87,2 \%$. Hal ini menunjukan bahwa persentase sumbangan pengaruh variabel independen (modal, pakan, pendidikan, usia petani, pengalaman berusaha, frekuensi pemeliharaan) terhadap variabel dependen (produksi) sebesar $87,2 \%$. Sedangkan sisanya sebesar $12,8 \%$ dipengaruhi oleh faktor lain yang tidak dimasukan ke dalam model penelitian.

\section{Tabel 3. Hasil Analisis Nilai Koefisien Determinasi $\left(\mathbf{R}^{2}\right)$}

\begin{tabular}{lcrcrc}
\hline \multicolumn{6}{c}{ Model Summary $^{\mathbf{b}}$} \\
\hline Model & R & R Square & $\begin{array}{c}\text { Adjusted R } \\
\text { Square }\end{array}$ & $\begin{array}{l}\text { Std. Error of } \\
\text { the Estimate }\end{array}$ & Durbin-Watson \\
\hline 1 & $0,934^{\mathrm{a}}$ & 0,872 & 0,838 & 0,781440 & 2,019 \\
\hline
\end{tabular}

\section{b. Pengujian F statistik}

Uji $F$ bertujuan untuk mengetahui ada atau tidaknya pengaruh simultan (bersamasama) yang diberikan variabel independen (modal, pakan, pendidikan, usia petani, pengalaman berusaha, frekuensi pemeliharaan) terhadap variabel dependen (produksi) ikan patin dalam keramba di Kelurahan Pahandut seberang. Adapun dasar pengambilan keputusan untuk uji $\mathrm{F}$ adalah: 1. Jika nilai signifikan $<0,05$ atau $F$ hitung > F Tabel maka terdapat pengaruh variabel independen terhadap variabel dependen; 2. Jika nilai signifikan >0,05 atau $\mathrm{F}$ hitung < F Tabel maka tidak terdapat pengaruh variabel independen terhadap variabel dependen. Dalam penelitian ini dapat diliat pada Tabel 4.

Tabel 4. Hasil Pengujian F Statistik

ANOVA $^{a}$

$\begin{array}{llllll}\text { Model } & \begin{array}{l}\text { Sum of } \\ \text { Squares }\end{array} & \text { Df } & \text { Mean Square } & \text { F } & \text { Sig. }\end{array}$




\begin{tabular}{llllll}
\hline Regression & 95,587 & 6 & 15,931 & 26,089 & $0,000^{\mathrm{b}}$ \\
Residual & 14,045 & 23 & 0,611 & & \\
Total & 109,632 & 29 & & & \\
\hline
\end{tabular}

Pengujian F statistik, dari output tabel ANOVA diatas diketahui nilai signifikansi untuk pengaruh semua variabel modal, pakan, pendidikan, usia petani, pengalaman berusaha, frekuensi pemeliharaan secara simultan terhadap Y adalah sebesar 0,000 < 0,05 nilai $\mathrm{F}$ hitung 26,089 > F tabel 2,53 sehingga dapat disimpulkan bahwa terdapat pengaruh modal, pakan, pendidikan, usia petani, pengalaman berusaha, frekuensi pemeliharaan terhadap Y (produksi) secara simultan artinya $\mathrm{H}_{0}$ ditolak dan $\mathrm{H}_{\mathrm{a}}$ diterima.

\section{c. Pengujian t Statistik}

Uji $\mathrm{t}$ dilakukan untuk mengetahui seberapa besar pengaruh yang diberikan masing-masing variabel independen (modal, pakan, pendidikan, usia petani, pengalaman berusaha, frekuensi pemeliharaan) secara parsial (sendiri) terhadap variabel terikat (produksi), dengan kata lain, untuk mengetahui apakah masing- masing variabel independen (modal, pakan, pendidikan, usia petani, pengalaman berusaha, frekuensi pemeliharaan) dapat menjelaskan perubahan yang terjadi pada variabel dependen (produksi) secara nyata. Adapun dasar pengambilan keputusan untuk uji t yaitu : 1. Jika nilai signifikan < 0,05, atau t hitung > t Tabel maka terdapat pengaruh variabel independen terhadap variabel dependen; 2. Jika nilai signifikan > 0,05 atau $\mathrm{t}$ hitung $<\mathrm{t}$ tabel maka tidak terdapat pengaruh variabel independen tehadap variabel dependen.

Untuk mencari nilai $\mathrm{t}$ tabel maka dilakukan perhitungan sebagai berikut:

$$
\begin{aligned}
& \text { Rumus } \mathrm{t} \text { tabel }=\mathrm{t}(\alpha / 2 ; \mathrm{n}-\mathrm{k}-1) \\
& \text { Keterangan : } \\
& \alpha \text { : tingkat kepercayaan } \\
& \mathrm{n} \text { : jumlah sampel } \\
& \mathrm{k} \text { : variabel independen } \\
& \mathrm{t}=(0,05 / 2 ; 30-6-1) \mathrm{t}=(0,025 ; 23) \\
& \mathrm{t}=2,069
\end{aligned}
$$

Tabel 5. Hasil Analisis Regresi Uji t-test Statistik

Coefficients $^{\text {a }}$

\begin{tabular}{lcrrrc}
\hline \multicolumn{7}{c}{ Unstandardized } & \multicolumn{2}{c}{ Standardized } & & \\
Model & \multicolumn{2}{c}{ Coefficients } & Coefficients & & Sig \\
\hline (Constant) & $-0,267$ & Std. Error & Beta & t-hitung & 0,836 \\
Modal & $0,023^{* * *}$ & 1,272 & & $-0,761$ & 0,002 \\
Pakan & $0,237^{* *}$ & 0,007 & 0,508 & 3,415 & 0,036 \\
Pendidikan & 0,049 & 0,066 & 0,236 & 2,226 & 0,469 \\
Usia & $-0,042$ & 0,035 & $-0,126$ & $-1,214$ & 0,237 \\
Pengalaman & 0,058 & 0,056 & 0,107 & 1,031 & 0,313 \\
Frekuensi & $0,226^{* * *}$ & 0,088 & 0,311 & 2,566 & 0,017 \\
Pemeliharaan & & & & & \\
\hline
\end{tabular}




\section{Variabel Modal (X1)}

Diketahui nilai signifikan untuk pengaruh variabel independen yaitu modal (X1) terhadap variabel dependen yaitu produksi (Y) adalah sebesar 0,002 yang artinya nilai 0,002 $<0,05$ dan nilai t hitung 3,415 $>\mathrm{t}$ tabel 2,069 artinya $\mathrm{H}_{0}$ ditolak dan $\mathrm{H}_{\mathrm{a}}$ diterima sehingga dapat disimpulkan hipotesis pertama yaitu modal diterima yang berarti terdapat pengaruh variabel modal (X1) terhadap produksi (Y). Hal ini mengindikasikan jumlah modal yang tinggi akan meningkatkan hasil produksi, dimana modal yang tersedia akan mempengaruhi produksi, karena dalam proses produksi dibutuhkan biaya-biaya yang digunakan baik untuk membeli pakan, vitamin, penambahan unit keramba, pemilihan bibit yang berkualitas, biaya penyusutan alat dalam budidaya. Apabila jumlah modal yang tersedia dapat memenuhi seluruh kebutuhan dalam proses produksi, maka proses produksi akan berjalan lancar dan pada akhirnya akan berpengaruh pada hasil produksi.

\section{Variabel pakan (X2)}

Diketahui nilai signifikan untuk pengaruh variabel independen yaitu pakan (X2) terhadap variabel dependen yaitu produksi (Y) adalah sebesar 0,114 dimana nilai $0,036<$ 0,05 dan nilai t hitung 2,226 > t tabel 2,069 artinya $\mathrm{H}_{0}$ ditolak dan $\mathrm{H}_{\mathrm{a}}$ diterima sehingga dapat disimpulkan bahwa variabel pakan diterima yang berarti terdapat pengaruh variabel pakan (X2) terhadap produksi (Y). Pengaruh pakan sangat besar dalam meningkatkan produksi, pakan yang berkualitas mmberikan kecukupn gizi bagi ikan sehingga mampu mengurangi tingkat kematian, pakan dalam penelitian ini berpengaruh cukup besar dengan tingkat kepercayaan 96,4\% memberikan pengaruh terhadap produksi ikan patin dalam keramba.

\section{Variabel pendidikan (X3)}

Diketahui nilai signifikan untuk pengaruh variabel independen yaitu pendidikan (X3) terhadap variabel dependen yaitu produksi (Y) adalah sebesar 0,469 yang artinya nilai 0,469 $>0,05$ dan nilai thitung $0,737<\mathrm{t}$ tabel 2,069 artinya $\mathrm{H}_{0}$ diterima dan $\mathrm{H}_{\mathrm{a}}$ ditolak, sehingga dapat disimpulkan hipotesis ketiga yaitu variabel pendidikan ditolak yang berarti tidak ada pengaruh variabel pendidikan (X3) terhadap produksi (Y). Hal ini terjadi karena pembudidaya ikan patin yang ada di Kelurahan Pahandut Seberang mayoritas hanya lulus SD.

\section{Variabel usia (X4)}

Diketahui nilai signifikan untuk pengaruh variabel independen yaitu usia (X4) terhadap variabel dependen yaitu produksi (Y) adalah sebesar 0,237 yang artinya nilai $0,237>0,05$ dan nilai $\mathrm{t}$ hitung $-1,214<\mathrm{t}$ tabel 2,069, artinya $\mathrm{H}_{0}$ diterima dan $\mathrm{H}_{\mathrm{a}}$ 
ditolak, sehingga dapat disimpulkan hipotesis ketiga yaitu variabel usia ditolak yang berarti tidak ada pengaruh variabel usia (X4) terhadap produksi (Y). Dalam penelitian ini variabel usia tidak berpengaruh terhadap roduksi, hal ini tidak lepas dari pengaruh faktor-faktor lain seperti pendidikan, karena rata-rata pembudidaya tamatan SD.

\section{Variabel pengalaman (X5)}

Diketahui nilai signifikan untuk pengaruh variabel independen yaitu pengalaman (X5) terhadap variabel dependen yaitu produksi (Y) adalah sebesar 0,388 yang artinya nilai 0,313 $>0,05$ dan nilai t hitung $1,031<\mathrm{t}$ tabel 2,069 artinya $\mathrm{H}_{0}$ diterima dan $\mathrm{H}_{\mathrm{a}}$ ditolak, sehingga dapat disimpulkan hipotesis ketiga, yaitu variabel pengalaman ditolak yang berarti tidak ada pengaruh variabel pengalaman (X5) terhadap produksi (Y). Hal ini dikarenakan pembudidaya tidak memiliki pengalaman yang cukup dalam membudidayakan ikan patin dalam keramba hal ini dapat dilihat dari data pengalaman responden, pengalaman juga dipengaruhi oleh kegiatan-kegiatan yang dilakukan instansi terkait seperti penyuluhan sehimgga memberikan wawasanwawasan baru atau terlatih bagi pembudidya.

6. Variabel frekuensi pemeliharaan (X6)

Diketahui nilai signifikan untuk pengaruh variabel independen yaitu frekuensi pemeliharaan (X6) terhadap variabel dependen yaitu produksi (Y) adalah sebesar 0,017 yang artinya nilai $0,017<0,05$ dan nilai t hitung 2,566> t tabel 2,069 artinya $\mathrm{H}_{0}$ ditolak dan $\mathrm{H}_{\mathrm{a}}$ diterima, sehingga dapat disimpulkan yaitu variabel frekuensi pemeliharaan diterima yang berarti ada pengaruh variabel frekuensi pemeliharaan (X6) terhadap produksi (Y). Frekunsi pemeliharaan memberikan pengaruh terhadap peningkatan produksi usaha ikan patin dalam keramba, setiap aktivitas pemeliharaan yang dilalukan seperti pengontrolan keadaan keramba, pengecekan kondisi ikan dan lain-lain dapat meminimalkan kegagalan produksi misalkan kebocoran keramba, kematian ikan dikarenaka kualitas air yang tidak baik sehingga dengan adanya frekuensi pemeliharaan ini mampu mengurangi tingkat kematian ataupun kegagalan panen.

\section{KESIMPULAN DAN SARAN}

\section{Kesimpulan}

Berdasarkan hasil penelitian yang telah dilakukan, maka dapat disimpulkan bahwa nilai koefisien determinasi sebesar 0,872 artinya sebesar $87,2 \%$ produksi ikan patin dalam keramba di Kelurahan Pahandut Seberang dipengaruhi oleh variabel independen yaitu modal, pakan, pendidikan, usia petani, pengalaman berusaha dan frekuensi pemeliharaan. Sementara sisanya sebesar $12,8 \%$ dipengaruhi oleh faktor 
lain yang tidak dimasukan ke dalam model penelitian. Secara simultan modal, pakan, pendidikan, usia, pengalaman dan frekuensi pemeliharaan berpengaruh secara signifikan terhadap produksi ikan patin dalam keramba di Kelurahan Pahandut Seberang Kota Palangka Raya. Secara parsial faktor modal, pakan, frekuensi pemeliharaan berpengaruh secara signifikan terhadap produksi ikan patin dalam keramba di Kelurahan Pahandut Seberang Kota Palangka Raya. Sementara faktor pendidikan, usia dan pengalaman secara persial berpengaruh tidak signifikan terhadap produksi ikan patin dalam keramba di Kelurahan Pahandut Seberang Kota Palangka Raya.

\section{Saran}

Berdasarkan masalah diatas maka disarankan:

1. Kepada pembudidaya ikan patin dalam keramba diharapkan dapat memperhatikan faktor modal, pakan dan frekuensi pemeliharaan sehingga dapat meningkatkan produksi ikan patin dalam keramba.

2. Kepada pemerintah daerah, kiranya dapat memberikan bantuan dengan cara pemberian kredit usaha murah terhadap para petani yang kurang mampu, serta memberikan pembinaan yang intensif terhadap petani untuk meningkatkan kualitas produksi perikanan ikan segar.
3. Kepada kalangan akademisi, diharapkan dapat menambah pengetahuan sekaligus menjadi refrensi pemilihan objek penelitian selanjutnya dan diharapkan dapat lebih memperhatikan dalam menentukan atau menambah faktor penelitian lain yang belum terdapat dalam penelitian ini.

\section{DAFTAR PUSTAKA}

Algifari. 2000. Analisis Reegresi: Teori, Kasus, dan Slousi, Edisi Kedua. BPFE. Yogyakarta.

Arikunto, Suharsimi. 2010. Prosedur Penelitian: Suatu Pendekatan Praktik (Edisi Revisi). Rineka Cipta. Jakarta

Badan Pusat Statistik Kalimantan Tengah. 2013. Sensus Pertanian. Badan Pusat Statistik Kalimantan Tengah. Palangka Raya.

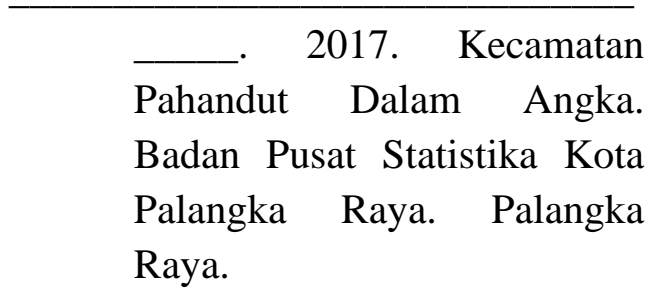

Dinas Kelautan dan Perikanan Provinsi Kalimantan Tengah. 2015. Potensi Pengembangan Perikanan Budidaya di Provinsi Kalimantan Tengah. Palangka Raya.

2016. Rencana Strategi Dinas 
Kelautan dan Perikanan

Provinsi Kalimantan Tengah

Tahun 2016-2021. Palangka

Raya.

2017. Produksi PErikanan

Budidaya Menurut

Kabupaten/Kota dan Jenis

Budidaya di Provinsi

Kalimantan Tengah (ton).

Palangka Raya.

Hidayatullah, Arief. 2016. Analisis

Faktor-Faktor yang

Mempengaruhi Produksi

Usaha Keramba Ikan Mas di

Kecamatan Babirik Kabupaten

Hulu Sungai Utara.

Universitas Islam Kalimantan.

Banjarmasin.

Kurnianti, A.S. dan Jumanto. 2017.

Strategi Pengembangan Usaha

Ikan Nila di Kabupaten

Kuntan Singingi. Provinsi

Riau. Riau. Vol. 19.

Rukmana, R.H. dan Herdi

Yudirachman. 2015. Sukses

Budidaya Ikan Nila Secara

Intensif. Lily Publisher.

Yogyakarta.

Soekartawi. 2002. Agribisnis: Teori

dan Aplikasinya, PT. Raja

Grafindo Persada, Jakarta. . 2003. Teori Ekonomi

Produksi Dengan Pokok

Bahasan Analisis Fungsi Cobb

Douglas. CV. Rajawali.

Jakarta. 